\title{
AHMET VEFIK PAŞA VE TÜRK DiLINE KATKILARI
}

\section{Ahmet Vefik Paşa and His Contributions to Turkish Language}

\author{
Dr. Hanifi VURAL ${ }^{*}$ \\ Dr. Tuncay BÖLER
}

ÖZ

Ahmet Vefik Paşa hem devlet kademesinde aldığı görevler hem Türk dili karşısındaki tavrı hem de Türk dili sahasında ortaya koyduğu eserler ile döneminin önemli isimlerinden birisidir.

Ahmet Vefik Paşa, devrindeki diğer sözlüklerden farklı olarak, Lehce-i Osmaniye Arapça ve Farsça kelimeler yanında Türkçe kelimeleri de almış, Zor Nikâhı adlı eserinde zamanın aydınlarını dil tutumları bakımından zor duruma sokan iğnelemeler yapmaktan çekinmemiş ve Zoraki Tabip'te çağdaşlarının ağdalı bilim dili anlayışıyla günlük konuşma dili arasındaki ayrılı̆̆ bir komedi unsuru olarak işlemiş ve böylelikle dilimiz karşısındaki hassasiyetini göstererek kendinden sonra gelecekler için örnek teşkil etmiştir.

Bu çalışmada Ahmet Vefik Paşa'nın hayatı üzerinde kısaca durulduktan sonra onun Türk diline katkılarından bahsedilmiş, ardından Türk dili ile ilgili eserleri tanıtılıp söz konusu eserler hakkında bilgiler verilmiştir.

Anahtar sözcükler: Ahmet Vefik Paşa, Lehce-i Osmani, Müntehabat-1 Durub-1 Emsal

\section{ABSTRACT}

Ahmet Vefik Paşa is one of the important figures of his time in terms of both official government duties he undertook and his attitudes towards Turkish language, as well as works he published about Turkish language.

Contrary to other contemporary dictionaries of the time, Ahmet Vefik Paşa included Turkish words in Lehce-i Osmani along with Arabic and Persian words. In Zor Nikâhı, he did not hold back his sarcastic critisism of contemporary intellectuals' attitude towards language. In Zoraki Tabip, he used the difference between his contemporaries' heavy science language and daily language as a comedic element and thereby set an example for the future generations by showing his sensitivity for our language.

In this study, we briefly touched upon Ahmet Vefik Paşa's life and disscussed his contributions to theTurkish language. We then introduced his works on Turkish language and gave information about these works.

Key words: Ahmet Vefik Paşa, Lehce-i Osmani, Müntehabat-1 Durub-1 Emsal.

\footnotetext{
* Gaziosmanpaşa Üniversitesi Fen-Edebiyat Fakültesi Türk Dili ve Edebiyatı Bölümü Öğretim Üyesi (hanifivural36@gmail.com)

** Gaziosmanpaşa Üniversitesi Eğitim Fakültesi Türkçe Eğitimi Bölümü Öğretim Ülyesi (tuncayboler@gmail.com)
} 


\section{Hayat}

11. Mahmut döneminde i̇stanbul'da doğan Ahmet Vefik Paşa'nın doğum tarihi hakkında elimizde kesin bir bilgi bulunmamaktadır'. ilk tahsilini aile çevresinden edindikten sonra 1831 yılında dedesinin de eskiden hocalık yaptığı Mühendishane-i Berri-i Hümayun'a girdi. Mühendishane-i Berri-i Hümayun'un ilk kısmını okuduktan sonra buradaki eğitimini tamamlayamadan 1834 yılında Paris Elçiliğine tayin olunan Mustafa Reşit Paşa'nın maiyetinde tercüman olarak Paris'e giden babasıyla birlikte İstanbul'dan ayrıldı. Eğitimine Saint Louis Lisesinde devam etti ${ }^{2}$. Paris'in en güzel lisesi olan bu okulda Ahmet Vefik Efendi'nin sinıf arkadaşlarından birinin de Alexandre Dumas (Fils) olduğu söylenmektedir ${ }^{3}$. Ahmet Vefik ìstanbul'da iken öğrenmeye başladığı Fransızcayı burada daha da geliştirdi; ayrıca Latince ve Grekçe eğitimi de aldı. Bütün bunları kolayca okuyup anlayacak düzeye geldi.

Mustafa Reşit Paşa'nın bir yıl sonra üç aylığına elçilikten ayrılmasıyla birlikte babası elçilik müsteşarlığına tayin edildi. Mustafa Reşit Paşa'nın ikinci kez Paris'e gelmesinden sonra Ahmet Vefik ve ailesinin Paris'te kalma süreçleri biraz daha uzamış oldu. Mustafa Reşit Paşa'nın buradaki görevinden 1837 yılında ayrılmasından bir müddet sonra Ruhiddin Efendi de istanbul'a döndü. Ahmet Vefik aynı yıl daha önce dedesinin ve babasının da görev aldıkları Tercüme Odasında çalışma hayatına başladı. Bir müddet mütercim olarak çalıştıktan sonra hacegân$l i k^{4}$ rütbesine yükseltildi.

Ahmet Vefik, içinde yetişmiş olduğu muhit aracılığı ile edinmiş olduğu Doğu kültürünü Paris'te kaldığı süre içinde elde ettiği Batı kültürüyle birleştirince İstanbul'daki yerli ve yabancı oluşumların gözde kişisi olmaya başladı. Makam ve mevkice hızlı bir yükselme fırsatı buldu. Özellikle Batı kültürüne aşina olmasından dolayı, döneminde sıklaşan Osmanlı Devleti ve Batı dünyası arasındaki diplomatik ilişkiler çerçevesinde bilgi ve görev bakımından sıkça başvurulan bir

\footnotetext{
' Doğum yılı için Akün şu bilgileri vermektedir: "Doğum yılı için 1823 (H. 1238)'ten başlayıp 1813 (H. 1228)'e kadar çıkan farklı tarihler verilmektedir. Bunlardan, torununun bildirdiği 3 Temmuz 1823 (23 Şevval 1238) tarihi daha yaygın ise de, girdiği mektep ve tayin edildiği ilk vazifeler için gerekli yaş durumu, ayrıca vefatında yaşının yetmişi aşkın olduğuna dair beyanlar göz önünde tutularak doğum yılını 1818 veya 1819 almayı uygun görenlerden başka ibnülemin de 1238 kaydını 1228 şeklinde düzelterek 1813 olarak göstermeyi tercih etmiştir." [Akün (1), a.g.m., 143]. Bu ifadelerde "ibnülemin de 1238 kaydını 1228 şeklinde düzelterek 1813 olarak göstermeyi tercih etmiştir." denmesine karşılık ibnülemin, Son Sadrazamlar'da bu tarihi 1823 (23 Şevval 1238) olarak anmaktadır (Inal, a.g.e., 651).

${ }^{2}$ Tansel (1), a.g.m., 118-119.

${ }^{3}$ Akün (1), a.g.m., 144.

${ }^{4}$ Eskiden yüzbaşı rütbesinin karşılı̆̆ı olan bir sivil rütbe [Ferit Devellioğlu, Osmanlıca-Türkçe Ansiklopedik Lûgat (Eski ve Yeni Harflerle), Aydın Kitabevi Yayınları, Ankara 1995, s. 305].
} 
devlet görevlisi konumunda bulunmuş ve rütbesi kademe kademe yükselmiş, önemli görevlere getirilmiştir.

1840 (H.1256) yılında rabiaya ${ }^{5}$ yükseltilerek Mustafa Şekip Efendi maiyetinde elçilik kâtibi göreviyle Londra'ya gönderildi (inal 1982: 651). Londra, Ahmet Vefik için Avrupa'ya açılmış ikinci önemli kapıdır. Böylece, daha önce öğrendiği yabancı dillere İngilizceyi de ekleyecek ve kültürel donanım bakımından kendini daha da geliştirmiş olacaktır. Ahmet Vefik Paşa Londra elçiliğinde iki yıl görev yaptıktan sonra 1842 (H.1258) yılında kimi meseleleri araştırması göreviyle Sırbistan'a yollandı. Dönüşünde Tercüme Odası Birinci Sınıf Hulefalığına ve Yolcu Pasaportları Muayene Müdüriyetine atandı 1843 (H. 1259) yılında bazı görevler için İzmir'e gönderildi. 1845 (H. 1261) senesinde İzmir'den dönünce kendisine salise ${ }^{6}$ rütbesi verildi. Ahmet Vefik İstanbul dışındaki görevlere gidip geldikçe her seferinde rütbesi yükseltilerek Tercüme Dairesinde görevlendirildi. Daha sonra teftiş amacıyla yeniden İzmir'e gönderildi. Dönüşünde Tercüme Dairesine mümeyyiz oldu.

1847'de yayımlanması kararlaştııılan ilk Salnaménin hazırlanması işi kendisine verildi. 1849 yılında kadrosunun bulunduğu dairede, Tercüme Dairesinde, baştercümanlığa terfi ettirildi. Aynı yıl Macaristan mültecileri meselesini çözme görevi ona verildi. Bu görev onun diplomatik zekâ ve becerisine duyulan güven bakımdan önemliydi. Nitekim verilen bu görevleri başarıla yerine getirmesi üzerine Mustafa Reşit Paşa, padişahtan aldığı izinle kendisine tahsinname gönderdi.

Kaynaklara göre 1849 yılında dünyaca ünlü Fransız şairi Lamartine, dönemin sadrazamı Mustafa Reşit Paşa'ya Türkiye'ye yerleşmek istediğini bildirir ve toprak talebinde bulunur. Bu isteği makul karşılanan Lamartine'e Aydın civarında bir çiftlik verilir. Bu işleri Lamartine adına takip etmek için şairin arkadaşı ve vekili seyahatname sahibi Charles Roland'ın Aydın'a gidişinde devleti temsilen eşlik etmek üzere Ahmet Vefik görevlendirilir.

Aydın dönüşünden sonra 2l Mart 1850'de Memleketeyn (Ulah ve Boğdan) Fevkalade Komiserliğine atand ${ }^{7}$. Bu atama haberini Rumen halkı beklenenin ötesinde bir sevinçle karşıladı. Ahmet Vefik, buradaki görevi süresince Türk menfaatlerini ön planda tutmak kaydıyla Rusya karşısında Rumen halkının yanında yer almış ve Rus entrikalarını önleyebilmiştir.

\footnotetext{
${ }^{5}$ Tanzimattan sonra kolağası derecesinde olan sivil memurlukta bir rütbe, elkabı "fütüvvetlü"dür (Devellioğlu, a.g.e., 871).

${ }^{6}$ Binbaşılık derecesinde mülki bir rütbe olup elkabı "rif atlü"dür (Devellioğlu, a.g.e., 917).

${ }^{7}$ Mehmed Süreyya, Sicill-i Osmanî l, hzl. Nuri Akbayar, Eski Yazıdan Aktaran: Seyit Ali Kahraman, Tarih Vakfi Yurt Yayınları, istanbul 1996, s. 225.
} 
1851 (H. 1262) yılında önce Encümen-i Daniş Üyeliğine daha sonra da Tahran Büyükelçiliğine atandı. İran'da Osmanlı Devleti'nin büyüklügüne yaraşır bir vakarla görevini ifa etmiş ve ilk defa Tahran'da bulunan Osmanlı Elçiliği binasına Osmanlı sancağını astırmıştır. Ayrıca Doğu kültürünün önemli bir bölümünü oluşturan Fars dünyası, meraklı bir münevver olan Ahmet Vefik Efendi için yepyeni bir ortam demekti. Nitekim o da burada geçirdiği dört yılını dolu dolu yaşayarak hem Farsçayı yerinde öğrenme hem de İran kültürünü daha yakından tanıma firsatı buldu.

Paris elçiliği yıllarında Ahmet Vefik'i yakından tanımış ve bir bakıma keşfetmiş olan Mustafa Reşit Paşa 1855 yılında sadrazam olunca onu Meclis-i Vâlâ-yı Ahkâm-1 Adliye Üyeliğine atadı. Bu Meclis, yüksek düzeydeki devlet görevlilerinin bulundukları mevkiden alındıklarında üye olarak atandıkları bir kurul niteliğindedir. Dolayısıyla Ahmet Vefik de bundan sonra her azil sonucunda bu Kurula üye olarak atanacaktır.

1857 (H. 1273) yılında Mustafa Reşit Paşa'nın sadrazamlı̆̆ döneminde Deavi Nazırlı̆̆ı (Adalet Bakanlığı)na atandı. Osmanlı Devleti'nin son dönemlerinde göreve atama ve görevden alma aralıkları gittikçe kısalmaya başlamış yüksek mevkilerdeki bürokratlar daha çok başa geçen sadrazamların yakın çevresinden olup olmamalarına göre muamele görmüşlerdir. Yine bu kural devrededir ve Deavi Nazırlı̆̆ görevinde bulunan Ahmet Vefik Efendi Sadrazam Mustafa Naili Paşa'nın ikinci sadrazamlı̆̆ sırasında bu görevinden alınarak Meclis-i Vâlâ-yı Ahkâm-ı Adliye Üyeliğine atandı.

1859'da Kıbrıslı Mehmet Emin Paşa'nın sadrazamlı̆̆ı sırasında Ahmet Vefik Paris Büyükelçiliğine atandı. Bu görevi sırasında devletin yüksek menfaatleri için yararlılıklar gösteren Ahmet Vefik 1861 yılında yerine Veliyüddin Paşa'nın tayin edilmesiyle Meclis-i Vâlâ Üyeliğine atanarak İstanbul'a döndü. Aynı yıl Fuat Paşa'nın kurduğu kabinede Evkaf-ı Hümayun Nazırı (Vakıflar Bakanı) oldu. Bakanlığı döneminde Süleymaniye Camiinin restorasyonu sırasında gösterdiği üstün gayreti sonucunda ikinci sıradan Osmanlı nişanına layık görüldü.

Evkaf-ı Hümayun Nazırlığı görevinde altı ay gibi kısa bir süre kaldıktan sonra 1862 (H. 1278) yılında Fuat Paşa tarafından kurdurulan ve mali ıslahatları düzenleyecek olan Divan-ı Âlî-i Muhasebat Başkanlığına getirildi. Bütçe teftişi ve diğer önemli mali işler yetki alanında iken ve bu alanda yapacağı birçok düzenleme varken Sırpların bölgede çıkardıkları karışıklıklar üzerine Belgrat'a görevlendirildi. Görevi olayları yerinde incelemek ve büyük devletlerin devreye girmesini gerektirecek bir durumun oluşumuna meydan vermeyecek tedbirler almaktı.

${ }^{8}$ Mehmet Zeki Pakalın, Ahmet Vefik Paşa, Ahmet Sait Matbaası, ìstanbul 1942, s. 6; İnal, a.g.e., 652. 
Belgrat'ta iki ay süreyle üzerine düşenleri başarıyla yaptıktan sonra Sırp meselesi ile ilgili konferansa katılmak üzere 16 Ağustos 1862 'de ìstanbul'a döndü ve Divan-ı Âlî-i Muhasebat Başkanlığı görevine devam etti. Bu görevde ancak altı ay kalabilen Ahmet Vefik 1863 yılında yeniden Meclis-i Vâlâ Kavanin Dairesi Üyeliğine atand.

19. yüzyılın ikinci yarısı Osmanlı Devleti'nin mali ve idari birtakım düzenlemelere gittiği bir dönemdir. Sık sık yeni kurumlar ihdas ediliyor ve etkin bir yönetim oluşumuna azami çaba sarf ediliyordu. Bu anlamda başvurulan yollardan biri de teftiş mekanizmasını etkin kılmaktı. Ahmet Vefik, Sadrazam Yusuf Kâmil Paşa'nın yönetimde olduğu 1863 yılında Anadolu sağ kol müfettişi olarak görevlendirildi. Teftiş alanında Kocaeli, Bursa, Biga, Balıkesir, Manisa, Muğla, Aydın, Antalya, i̇çel il ve ilçeleri vardı. Ciddi ve titiz devlet adamı kimliği ile verilen her görevde olduğu gibi müfettişliğinde de devletin yüksek menfaatleri uğruna yapıp ettikleriyle bir kısım halkın tepkisini çekti. Özellikle Bursa halkından gelen şikâyetler üzerine 1864 yılında yirmi ay kadar süren sağ kol müfettişliği görevinden el çektirildi. Bütün bu görevlerden alınmasında etkin rol oynayan rakipleri son azlinden sonra da yürütülen soruşturmada nüfuzlarını kullanarak emekli edilmesine aracilık etmiş oldular. Gelinen bu nokta, Ahmet Vefik Efendi'nin Rüştü Paşa'nın ve devamında Ali Paşa'nın sadrazamlı̆̆ döneminde yedi yıl gibi uzun bir süre zarfında devlet işlerinden uzak kalması demekti. Bu süre zarfında geçimini sağlaması için kendisine mazuliyet maaşı bağlandı

Devlet kapısından, dolayısıla hizmetinden alıkonan Ahmet Vefik, birtakım sıkıntılarla baş başa kalmasına rağmen hayata sırt çevirmedi. Sahip olduğu kültürel bilgi ve birikimini devreye sokarak dil, tarih ve edebiyat alanlarında çalışmaya, eser ortaya koymaya çalıştı. Molière'den tercümeler yazı hayatının ilk tecrübeleridir. Bunları okullar için hazırladığı Fezleke-i Tarih-i Osmani, Türkî Durub-ı Emsal ve Hikâye-i Hikemiyye-i Mikromega takip etti. Hayatının önemli bir bölümünü devleti ve milleti için idari ve siyasi hizmetlerle geçiren Ahmet Vefik söz konusu yollardan mahrum bırakılınca da boş durmamış hizmet kanalını değiştirerek kültür dünyamıza önemli katkılar sağlamıştır.

Sadrazam Ali Paşa'nın ölümünden sonra yerine geçen Mahmut Nedim Paşa'nın sadrazamlığı, maddi manevi sıkıntılar içinde bulunan Ahmet Vefik Efendi için de yeni bir dönemin habercisiydi. Nitekim 1871 yılında Rüsumat Emini olarak atandı ve ardından mecidi nişanına layık görüldü. Hassas mizacı, görevine son derece bağ $l_{1} \operatorname{l̆ğ}_{1}$ ve doğru bildiklerinden taviz vermeyen kişiliği yüzünden bu dönemde de kısa aralıklarla görev değişikliğine tâbi tutulmuş, atandı̆̆ görevlerde pek de rahat edememiştir. Rüsumat Eminliğinde dört ay kaldıktan sonra 1872 yılının başlarında Refik Bey'in yerine Sadaret Müsteşarlığına getirildi. Yaklaşık 
olarak dört ay sonra bu görevden de alınarak Maarif Nazırlığına atandı. Bu görevi sırasında eğitimin yaygınlaşması için önemli tedbirler aldı.

Mütercim Rüştü Paşa'nın sadrazamlığı ile birlikte yaşanan kabine değişikliği sonrasında kendisine Şûra-yı Devlet Azalı̆̆ verildi. Tarih tekerrür etti ve bu son görevinde dokuz ay bile kalamadan yeniden azledildi.

Azledilişiyle üç buçuk yıl kadarlık süre zarfinda devlet hizmetlerinden uzak kalınca yeniden kalem ve nesir faaliyetlerine başladı. Bu süre zarfında ilk cildini yayımlamış olduğu Lehce-i Osmani, Türk sözlükçülüğü bakımından bir dönüm noktası niteliğindedir.

1876 (H. 1292) yılında Ahmet Vefik Paşa'ya Petersburg Cemiyet-i ilmiyesinde Türkiye'yi temsil etme görevi verildi. 5 Şubat 1877 'de ilk Meclis-i Mebusanın Başkanlığına getirildi. Kısa bir süre sonra Meclisin 19 Mart 1877'de açılmasıyla birlikte vezir olarak görevlendirildi ve dolayısıyla "paşa"lık unvanını elde etmiş oldu.

Meclis-i Mebusan ilk çalışma devresini üç ay gibi bir zaman dilimi içinde tamamlayınca Ahmet Vefik Paşa da 24 Ağustos 1877'de Edirne valiliğine tayin edildi. Rusların Balkanlara yönelik hareketlerinden dolayı stratejik bir mevki olan Edirne valiliğine birikim ve deneyiminden dolayı atanan Ahmet Vefik Paşa, sağlı$\breve{\text { ğ }}$ nedeniyle üç ay sonra bu görevden alınarak yeniden çalışmalarına başlayan Ayan Meclisi Üyeliğine tayin edildi.

Il Ocak 1878'de ikinci kez Maarif Nazırlı̆gna getirildi. Aradan bir ay bile geçmeden, yirmi beş gün sonra başvekil oldu. Başvekilliği sırasında Dâhiliye Nazırlı̆̆ını da uhdesinde bulunduran Ahmet Vefik Paşa, 14 Şubat 1878'de Meclisin dağılmasından sonra aynı yılın Mart ayında Bursa valiliğine tayin edildi. Bursa valiliği sırasında bir taraftan idari hizmetlerde bulunurken diğer taraftan da edebî faaliyetlerine ă̆ırlık verdi. Birçok tercümesi ve Müntehabat-ı Durub-ı Emsal adlı eseri Bursa'da geçirdiği günlerin ürünleridir.

16 Ekim 1882' de valilik görevinden azledilince İstanbul'a döndü.

30 Kasım 1882'de yeniden başvekilliğe atandı; fakat bu son görevi sadece üç gün sürdü. Bundan sonra artık devlette görev alamayan Ahmet Vefik Paşa, kalan ömrünü Rumelihisarı'ndaki köşkünde kitaplarının arasında geçirdi. Köşkünde çok da rahat geçirmediği yaklaşık dokuz buçuk sene zarfında Lehce-i Osmani nin ikinci cildini de tamamlayarak iki cildi tek kitap olarak yayımladı.

1 Nisan 189l'de hayata veda eden Ahmet Vefik Paşa'nın cenazesi Rumelihisarı'nda Kayalar Mezarlığına defnedildi. 


\section{Türk Diline Katkıları}

Ahmet Vefik Paşa'nın dilimize olan katkılarından bahsederken Paşa'nın dil konusundaki bilinçli tavrını burada hemen ifade etmek gerekir ${ }^{9}$. Kaba Türkçe

${ }^{9}$ Bu bakımdan lgnácz Kúnos'un Türk Halk Edebiyatı adlı çalışmasında anlattığı şu anekdotu buraya alıyoruz:

Bir tavsiye mektubum daha vardı. O da Ahmet Vefik Paşa adına... Adı geçen Lehce-i Osmânînnin sayın yazarıdır. Paşa'nın kim olduğunu, o eserlerinin, tercümelerinin şöhretini zaten önceden öğrenmiştim. Bir gün erkenden kalkıp, Boğaziçi'nin bir dilenci vapuruna binerek Paşa'nın oturduğu Rumelihisarı'na gittim.

Paşa'nın köşkü tepede imiş... İsmi köşk amma saraya benzer bir bina idi. Oraya giderek Vambery'nin mektubu vasıtasıyla Paşa'nın huzuruna çıktım. Geniş kütüphanesinde Avrupa tipi bir koltuk sandalyede oturup beni öyle sevimli bir surette kabul etti ki, âdeta mahcup kaldım.

Paşa'nın davranışı şahane, bakışı merdane; yüzündeki zekâvet, sözündeki keramet bana öyle tesir etti ki, kırk üç yıl geçtikten sonra hayali hâlâ gözümün önünden gitmez. Niyetimi, ziyaretimin sebebini anlatırken, nazik bir şekilde;

- Demek ki Avrupa şarkiyatçılarının sırasında yer bulmak niyetindesin, aferin sana aferin! dedi. Ben: O muradıma ermeden önce Türkçe öğrenmeliyim "folklor" dedikleri edebiyatın türlü türlü izlerini arayıp bulmalıyım.

Paşa: Çok arayacak olursan, zahmetlerden çekinmezsen elbette nail olursun. Acaba şimdiye kadar bu yolda tecrübelerin var mı?

Paşa'nın bu sorusu üzerine, Rumeli'de toplamış olduğum türküleri mendilimden çıkarıp birer birer okudum. Bu halk şiirleri sayın bilginin çok hoşuna gitti.

- Ha, dedi, benim de fikir aldığım parçalar bunlardır. Yolun doğrusunu artık buldun. Bu yoldan hiç sapma.

Bana çok minnet veren bu sözlerden sevinerek:

- Lehce'nizde avam lügatleri bol bol bulunuyor, deyince Paşa:

- Vay! Benim Lehce'mi gördün mü? diye sordu.

Ben: Yalnız görmek değil, hatta okudum bile... Hemen iskemlesinden kalkıp, Lehce'sinin güzel ciltlenmiş bir nüshasını aldı ve bana hediye etti.

Paşa: Lehce'mde bulunmayan avam lügatlerine rastgelip yazarsan, kitabımı tamamlamış olursun.

Ben: Memnunlukla... diyerek, kendilerine teşekkür ettim.

(...)

Türkü söylenmesi biter bitmez.

- Efendim bu öyle adi türkülerden değil... Âdeta bir "Ballad”a benziyor. Bunun gibi beyitler Batı edebiyatında bile az bulunur... dedim.

Paşa: Ben de bilmiyordum başkasını... İşittiğim yalnız bir tanedir. Dediğin Ballad'lar zaten facia olduktan başka, karşııklı konuşmaları da vardır.

Paşa hazretleriyle "Türkü" gibi beyitler üzerine uzunca konuşma açıldı.

Paşa: Batı "avami edebiyatı"nın en çoğundan benim de haberim var ve bunlara dair eserler de kütüphanemde mevcut... diyerek birtakım dergiler gösterdi.

Ben: Öyle ise, İslam memleketlerinin çoğunda niçin bunun gibi eserler yok?

Paşa: Bunun birçok sebepleri vardır. En başkası, bizim Osmanlı dilinin millî bir dil olmaması, eski şairlerle bilginlerimizin ya Farisi veya Arabi edebiyatlarının tesiri altında dilimizi onların diline uydurmaya çalışmalarıdır. Şarkı, gazel ve bunun gibi şiirlerimiz, en fazla Arap ile Acem 
diye hor görülmüş halk dilinin sözlerini ve deyimlerini itibara kavuşturmak, Arapça ve Farsçanın tesiriyle unutulan kelimeleri yeniden ana dile kazandırmak, bu ikisinin hâkimiyeti altında esas kendi lügatindeki servetinden uzaklaşmış ifadeyi halk deyimlerine, onun kuytuda kalmış sözlerine ve geçmişteki Türkçenin kaynaklarına açmak. Ahmet Vefik Paşa'da nazariyat yerine tatbikatı ile ifadesini bulan millî dil ülküsü olmuştur ${ }^{10}$. Nitekim Ahmet Vefik Paşa'nın Lehce-i Osmaniye -döneminin diğer sözlüklerinden farklı olarak- Arapça ve Farsça kelimelerden başka Türkçe kelimeleri de alması kendisinin dil konusundaki söz konusu hassasiyetine işaret etmektedir. Denilebilir ki Ahmet Vefik Paşa Lehcésine Türkçe sözleri de alarak Osmanlı'nın lisan denizine gark olmuş Türkçe kelimelerin çokluğunu ve bunların ehemmiyetini göstermeye çalışmıştır.

Bundan başka Ahmet Vefik Paşa Türk dilinin kelime yapmak ve ecnebi dillerinden alınan kelimeleri kendi tasarrufuna almak hususundaki kabiliyetlerini ortaya koyarak kendisinden sonra geleceklere dilin hâkimiyet ve istiklali sahasında güzel bir örnek vermeye çalışmıştır. Türk dilleri hakkında da Lehce-i Osmani Mukaddimesinde şu malumatı vermiştir: Elsine-i Türkîde en mukaddem münteşir olan Oğuz şu'besi Tataristân ve Türkistânı bir zamân Bahr-i Şarkîden Macaristan'a kadar kavrayıp hâlâ Guz lisânı denir anın yenisi Türkmen (Türkmân) lisânı Irân ve Sûriye'yi kaplayıp Anadolu'ya inmiş mürûr-ı zamân ile lehce-i Osmânîyi tevlîd etmişdir Fergâna'dan Hind'e doğru yayılıp Halacî lisânı Afgan'a karışmışdır eski şu'belerden Kıpçak lisânı Hive'den Sibir ve Kırgız ve Kuman ve Bulgar gibi Kazan etrâfinı istîlâ etmişdir. Ve Uygur dili Çin taraflarından Kâşgar'a doğru yayılıp andan yedi yüz târîhlerinde Çingizyân akvâmı Türk ve islâmiyyet'e duhûl eylediklerinde Çağatay lisânı mütevellid olup sekiz yüz a'vâmında ziyâde şüyû́' bulmuşdır. El-yevm Uygur ve Kıpçak ve Çağatay kitâbları Mahbûbu'l-Kulûb te'lîfi gibi güzel eserleri ve husûsen altı yüzden sekiz yüze kadar meydâna gelen Selâcık'a Türkmânî ve Osmânlı kitâbları kesretle tab' olunup bunların tetebbu'uyla lisânımızın şu'belerinin ihtilâfâtı anlaşılmalıdır.

Hiç kimsenin Türkçemizin diğer Türk lehçeleriyle ne gibi alakaları bulunduğu ve bu hususta tetkike lüzum olup olmadığını düşünmeye bile lüzum görmediği bir zamanda Ahmet Vefik Paşa'nın bu mesele ile uğraşması Türkçe kelimeleri canlandıracak bir lugat yazmaya girişmesi diline ve milletine ne kadar

şairlerinin taklidi... Gitgide öyle bir Osmanlı dili meydana gelmiş ki, söylenilen dilden gittikçe ayrılmış...

Ben: Hâlbuki, Türk dilinizin tabii güzelliği ve zenginliği var.

Paşa: Şüphe mi var... Bir de bunu ispat için işte benim "Atalar Sözü" dedikleri kitabım. İşte Molyer (Molière) oyunlarının tercümesi... Ve daha bunun gibi birkaç eser (Ignácz Kúnos, Türk Halk Edebiyatı, hzl. Tuncer Gülensoy, Tercüman 1001 Temel Eser, ìstanbul 1978, s. 40-44).

${ }^{10}$ Musa Duman, "Yenileşme Döneminde Türk Dili", Türkler Ansiklopedisi, C. 15, Yeni Türkiye Yayınları, Ankara 2002, s. 115. 
candan bağlı olduğunu göstermeye kâfidir". Ayrıca Harabat'ta Çağataycayı ayrı bir dil olarak gören ve eserinde Arapça, Farsça, Osmanlıca ile Çağatay dillerinden seçtiği metinlere yer verdiğini söyleyen Ziya Paşa'ya karşılık onun çağdaşı olan Ahmet Vefik Paşa'nın Oğuz dili, Uygur dili, Çağatay lisanı gibi tabirler kullanmakla birlikte zamanla Oğuz dilinin lehce-i Osmani'yi meydana getirdiğini ifade ettiği Lehce-i Osmani Mukaddimesi de onun Türkoloji bilgisinin çağdaşlarından ne kadar ileride olduğunu göstermesi bakımından önemlidir.

Diğer taraftan Ahmet Vefik Paşa'nın tiyatro eserlerine bakıldığında halka inen, halk dilini işleyen, halkın yaşantılarını, gelenek, göreneklerini yansıtan tiyatro anlayışını benimsediği görülmektedir. $\mathrm{O}$, gerçek hayattan uzak, sosyal düşüncelerle yüklü, soyut tiyatro anlayışını sevmez ve bu özelliğiyle Namık Kemal, Abdülhak Hamit yolunda gitmez. Ahmet Vefik Paşa tiyatro anlayışıla Şinasi'nin takipçisidir. Zaten bu tutum onun eserlerinin günümüze gelmesindeki en önemli etken olmuştur. Bugün için zamana boyun eğmiş olan Namık Kemal ve Abdülhak Hamit'in oyunları yanında Ahmet Vefik Paşa'nınkiler bizler için hâlâ canlı ve değerlidir. Ayrıca millîlik, onun uyarlamalarının en önemli tarafıdır. Ahmet Vefik Paşa uyarlamalarında Molière' in kahramanlarına Türk toplumunun gelenek ve göreneklerini temsil eden yerli ve millî bir kimlik kazandırmıştır. Başka bir tabirle o, uyarlamalarına yerli bir eser çeşnisi verebilmiştir. Hatta Paşa'nın manzum çevirilerinde ifadeyi zor kılacağı endişesiyle bile olsa aruzu bırakıp hece ölçüsünü seçmesinde de kendisini hissettiren millî bir tercihten bahsedilebilir. Bu itibarla Ahmet Vefik Paşa'nın tiyatro eserlerinin en dikkat çeken yönlerinden biri de kullanılan dildir ve Ahmet Vefik Paşa tiyatro eserlerinde Türk dili ile ilgili görüşlerini ortaya koyacak açılımlarda bulunmuştur. Mesela Zor Nikâhinda devrin aydınlarını, dil tutumları bakımından zor duruma sokan iğnelemeler yapmaktan çekinmemiştir. Eserden alınan şu küçük parça bu durumun güzel bir örneğidir:

Üstâd-ı Sânî: Peki ne diyeceksiniz bana bakayım. Hem de ne lisan kullanacaksınız?

ivaz Ağa: Ne lisan mı?

Üstâd-ı Sânî: Evet! Yani ne dille söyleşeceksiniz?

ivaz Ağa: (Bakındı) Ne dille imişs? Ne dil olacak. Işste ăğımdaki dil. Komşununkini kullanacak değilim ya.

Üstâd-ı Sânî: Canım öyle değil. Ne lisan, yani ne lügat, hangi lehçe? Arapça mı söyliyeceksiniz?

ivaz Ağa: Hayır.

Üstâd-ı Sânî: Farisî mi?

ivaz Ağa: Hayır.

Üstâd-ı Sânî: Ibranî?

"Pakalın, a.g.e., 205-206. 
ivaz Ağa: Hayır.

Üstâd-ı Sânî: Süryani?

ivaz Ağa: Hayır.

Üstâd-ı Sânî: Yunani?

ivaz Ağa: Hayır.

Üstâd-ı Sânî: Latini?

ivaz Ağa: Hayır.

Üstâd-ı Sânî: Fransızca mı?

ivaz Ağa: Hayır.

Üstâd-ı Sânî: Ingilizce mi?

ivaz Ağa: Hayır! Hayır!

Üstâd-ı Sânî: Nemsece, italyanca, Rumca, Ermenice, Hinduca?

ivaz Ağa: Hayır canım! Hayır! Hayır! I̦şte Türkçe söyleşiyoruz ya. Türkçe söylerim!

Üstâd-ı Sânî: Ey peki Türkçe olsun canım. Çünkü Türkçe söyliyeceksin, beri tarafa geç. Zira bu kulak elsine-i kadime ve ilmiyeye mahsustur. Öbür kulak elsine-i âdiye ve zeban-ı mâderzâdiye muayyendir (Zor Nikâhi, s. 32-34).

Bundan başka Ahmet Vefik Paşa Zoraki Tabip’te çağdaşlarının ağdalı bilim dili anlayışıyla günlük konuşma dili arasındaki ayrılığı bir komedi unsuru olarak işlemiştir. Bu eserin önemli kahramanlarından olan İvaz'ın zoraki hekim olarak yaptığı konuşmalarla günlük konuşmalar arasındaki büyük fark bu gerçeği aksettirmektedir:

ivaz: Yalan söylersin. Hepsini yemiyorum, birazını içiyorum.

Selime: Evde olan eşyamı birer birer satıp savan batakçı!

ivaz: Işste iyi ya! Bu, ev mahsulünden geçinmek demektir.

Selime: Yatağıma varınca kaldırıp götüren kaypakçı.

ivaz: Iyi ya!.. Göç kolay olur.

Selime: Sabahtan akşama kadar hemen içip içip kumarbazlık eden hayâsız!

ivaz: Ey, ne olmuş... Canım sıkılmasın diye ediyorum.Hekim (!) İvaz'ın konuşması:

ivaz: Işste efendim, ol vahâmat ve redâet zatürrüe ile hicabülcevfin inhidap ve ik'irarından tevellüt eden ahlâtın hamuzeti mülâbesesiyle mütehaddis olduğundan dolayı kabr ü harbin bimekân kafrin ve leyse kurb ü kabrin kubrün... Velmuzafünileyh imma müzafün. Işste tastamam bunun içindir ki kızın dili tutulmuştur (Zoraki Tabip, s. 1112). 
Bir başka örnek:

Üstâd-ı Sani: A. Ivaz Ağa! Zamanede her şey zîrü zeber; kişi kişiden bîhaber; hep gîr ü dâr ü gerr ü cer! Âlem umûmen dalâlete düstü; zîr-i destân bagy ü isyâna inhimakle birer hükümrân-ı zeberdest-i pürâzâr! Kimesnede perva kalmadı, tuğyân-ı âlemyân dehşetâmiz, tasaddiyât-i cihhâl fitneengiz! Nâzım-ı nizâm-ı umûr-ı cümhur ve kaasır-ı licâm-ı ehl-i şerr ü şûr makâmına mensup bulunan zâbitân-ı belde ve hâkimân-ı ülke hayâlarından ölsünler ve gussadan canların hedere versinler $k i$ bu çekilmez rezâlete ve hazolmaz şekâvete rızâ verirler; bir ân müsaade ve zecr ü tenkilden tarfetül'ayn gurabül beyin misâli müsâmaha ederler." (Zoraki Tabip, s. 28).

Ahmet Vefik Paşa'nın şuurlu dilcilerimizden biri olduğunu gösteren bir başka çalışması da Telemak tercümesidir. İsmail Habip Sevük, Yusuf Kâmil Paşa'nın Telemak tercümesini beğenmemekte ve bu tercümenin sözlükler olmadan anlaşılmasının mümkün olmadığına işaret etmektedir. Fakat, Sevük'ün belirttiğine göre Ahmet Vefik Paşa bizi bu durumdan kurtarmaktadır; çünkü, Yusuf Kâmil Paşa'nın dili ile Ahmet Vefik Paşa'nın dili arasında Doğu ile Batı kadar farklar söz konusudur ${ }^{12}$.

Yazı dilinde yer almayan, bir bölümü halk dilinde de terk edilen veya dilde mevcut olup da o anlamda kullanılmayan Türkçe kelimelere yer vermesi ve yabancı terkiplere, halk tarafından kullanılmayan Arapça, Farsça kelimelere hemen hiç yer vermemesiyle Ahmet Vefik Paşa'nın tiyatrolarında kullandığı dil kendinden öncekilerin, çağdaşlarının ve daha sonrakilerin eserlerinden ayrılmaktadır. Onun Lehce-i Osmanisi eserlerinin dili için yeri geldikçe kullanabileceği bir kaynak vazifesi görmüştür. Fevziye Abdullah Tansel'in deyimiyle tiyatro eserleri, tespit ettiği Türkçe kelimelerin muhtelif manalarının ifade kudretini canlandıran bir tatbikat sahnesi olmuştur' ${ }^{13}$.

Tiyatrolarından hareket edilerek oluşturulan aşağıdaki kelime listesi bu konuda esaslı bir fikir vermeye yeterlidir: acırak, afatlamak (kıyamet koparmak), ağlayışcık (bir iki gözyaşı), ağmak (yükselmek), albeni (cazibe), aldamak (hile ile zihin çelme, aldatmak), allak (hilekâr, dönek), aparmak (götürmek, aşırmak), arık (yağsız, etsiz, zayıf), balıklamak (sıçramak, debelenmek), bitür (haraç), bulangın (bulanık), burnaz (burnu büyük), cadaloz (cadı huylu), carcar/çarçar (yaygaracı,

${ }^{12}$ ìsmail Habip Sevük, Türk Teceddüd Edebiyatı Tarihi, Matbaa-i Âmire, İstanbul 1925, s. 309310 .

${ }^{13}$ Fevziye Abdullah Tansel (II), “Ahmet Vefik Paşa'nın Eserleri”, Belleten, Türk Tarih Kurumu Yayınları, C. XXVIII, S. 110, Ankara 1964, s. 265. 
geveze), cavlak (çıplak), cib (sırf, büsbütün), çalım (tavır), çaşıt/çaşut (casus), damadlanmak (damat edinmek), dibelek (dibe kadar), dilek etmek (arzu etmek), dilmaç (tercüman), dört ayaklı alafranga yataklık (karyola), dössek dayaklı (dayalı döşeli), düzce (sade, bayă̆̆), engel (mâni), esenleşmek (vedalaşmak), esrük (sarhos), ezgi (ezerek çıkarılan ses, terennüm), fikramak (kaynamak), fir fir aramak (acele ve heyecanla aramak), fodul (atak), geri (fazla, çok), gülecek (gülünç, gülünecek şey), harın (yorgun argın), hora geçirmek (horlamak, hakir görmek), iğti (acımtırak, keskin), inan (inanç), istek etmek/istek eylemek, işkil (zan, vesvese), kakımak (azarlamak, darılmak), kapançe (küçük kuş kapanı ve kapalı kafes), kerte (derece, menzil, mertebe), kışmirlik/kişmirlik (maskaralık, eziyet etmek), komak (birakmak, ikame etmek), kurumsak (kaltaban), mehlem (merhem), muşta (yumruk), nalet (lanet), nefeslenmek (nefes almak), oflaz/oflas (işgüzar, işe yarar, cesur, kabadayı), onat (münasip, güzel, övülmeye değer), ögül/ögil (öfkelenme), öperlemek (öpmek), öründelemek (atamak, tayin etmek, seçmek), pat/patadak (çabuk, birdenbire), postal (sürtük), ruskat (ruhsat), sadalamak (seslenmek), sağlamak (temin etmek), saklanbaç (saklanılacak, emin yer), salt (sade, yalnız, ancak), sasllı (küf ve nem kokusu), sezinlemek (his, derk etmek), sezinmek (anlayıp ses çıkarmamak), sınmak (kırılmak), sürç (günah, hata), talamak (talan etmek, vurmak), tırıl (zayıf, çıplak şey), torlak (genç, hovarda), tutum (muamele, hareket, tavir), uhruc (çık git, dışarı çık, defol), umu (umma, ümit etme), umurcu (itina edici), umursamak (vazife edinmek), urug (uruk, kabile, oymak), yab yab (sessiz sessiz, yavaş yavaş), yalav (alev), yangın (şikayet eden, yanıp yakılan), yanık (âşık), yankılyanku (akis), yanşık (ağzı yavan, geveze), yapınış (kırıtış gibi yapma eda), yavuk (yakın), yavuz (ședit, haşin), yermek/yirmek (aleyhinde bulunmak), yumak (yıkamak, temizlemek), yünsüz (uğursuz), zıngıldamak (oynamak, adamın işi şaşmak), zırlak (ziyade sesle zırlayan).

Yukarıdaki lügatçe gözden, geçirilince, Vefik Paşa'nın ruhsat, lanet gibi bazı yabancı kelimeleri halk dilindeki ruskat, nalet şeklinde kullandığı anlaşılır. Esrük, iğti, kurumsak, kışmirlik, öründelemek, sınmak gibi arkaik veya dilde yaşayan, fakat o manada kullanılmayan kelimelere sık sık rastlarız; bilhassa bu sonuncular oldukça kabarık yekûndadır; mesela tutum, saklanbaç kelimeleri "tavır, saklanılacak yer" manasında kullanılmıştır. Dilek etmek, istek etmek, sadalamak, damadlanmak, sezinlemek gibi fiiller, cib, yab yab vb. edatlar, yapınış, ağlayışcık gibi isimler, umurcu gibi sıfatlar onun tiyatrolarına dil bakımından nevi şahsına münhasır bir hususiyet vermiştir ${ }^{14}$.

Atasözleri, deyim ve halk tabirlerini sık sık kullanması, Ahmet Vefik Paşa'nın eserlerinde dikkatleri çeken ve onlara yerli bir renk katan başka bir yön-

${ }^{14}$ Tansel (11), a.g.m., 271. 
dür ve esasen onun hünerini de bu husus teșkil eder. Yine Lehce-i Osmani ve Atalar Sözü kitabı bu konuda ona kaynak teşkil etmiştir.

Tiyatrolarındaki bazı atasözleri: adamakla mal tükenmez, adam var dă̆ kaldırır, adam var bir darı kaldıramaz, ahmak sözüne kulak verilmez, alısmış kudurmuştan beterdir, arife bir söz hacet değil, arife tarif hacet değil, bağlu koyun yerinde otlar, beş parmak bir değildir, bir fiçı sirke bir sinek tutmaz, bir suçla adam kesilmez, can malın yongasıdır, denize düşen yılana sarılır, devlet başıma, kuzgun leşime, dil yarası asla onulmaz, geleceği varsa göreceği de var, gönül hoşluğu maldan iyidir, huylu huyundan geçmez, iki karpuz bir koltuğa sığmaz, kalpten kalbe yol olur, kanı kanla yumazlar; kanı su ile yuyarlar, kızım sana söylerim, gelinim sen dinle, kişinin izzeti de elindedir, zilleti de, o çamlar şimdi bardak oldu, öfke baldan tatlıdır, sakınan göze çöp düşer, sırrı söyleme dostuna, onun da dostu olur, sözle can beslenmez, yemişsiz ağaca kimse taş atmaz, yere bakar, canlar yakar, yerin kulağı var.

Tiyatrolarındaki bazı deyimler ve halk tabirleri: abayı yakmak, acı basmak (hiddetlenmek, üzülmek), açık kapı, ağa göndermek (tuzağa düşürmek), ağanın beygiri, ağız burun ekşitmek, ağzına bir parmak bal çalmak, ağzı pek, ağız kokusu, altın babası, ayak basmak, baldırı çıplak, bam teline basmak, baş ağrıtmak, biyık altından, bin dereden su getirmek, borusu ötmek, burnunu sokmak, can atmak, canı burnuna gelmek, çançanı tutmak (çene yarıştırmak), damarı tutmak, değirmende sakal ağartmak, eksik etek, faka basmak, gem vurmak, göz bağlamak, gözden sürmeyi çalmak, gözümün elifi, kaba kacağa sığmamak, kara yürekli, kaz kesilmek (ahmaklaşmak), keyif çatmak, kıl kadar, kurt masalı okumak (boş şeylerle aldatıp vakit kazanmak), mat olmak, ocağına düsmek, papuçlar dama atılmak, pişmiş aşa su katmak, rahat batmak, sakaldan kesip bıyığa eklemek, suyu saman altından yürütmek, taş atmak, uyur yılanın kuyruğuna basmak, yakayı ele vermek, yan çizmek, yelkenleri indirmek, yuva yapmak, yüreği yufka, yüz akı, yüze çıkmak, zinciri sürümek, zokayı yutmak.

Ahmet Vefik Paşa'da kimi zaman tamlamalar Türkçe tamlama kurallarıyla verilmiştir: muhayyir'ül-ukul yerine akıllar muhayyiri, zevk-i civanan yerine civanan zevki gibi. Paşa böyle yapmakla kendinden sonra gelecek olan Yeni Lisancilar ile enikonu örtüşmektedir. Nitekim Ahmet Vefik Paşa'dan daha sonra gelen Yeni Lisancılar nazar noktası, sanat eseri, dikkat nazarı gibi tabirlerin eser-i sanat, nokta-i nazar ve nazar-ı dikkat tabirlerine tercih edeceklerdir. Nitekim konu ile ilgili olarak Genç Kalemler Dergisinde şunlar kayıtlıdır: Türkçe sarfımızı tanıma$\mathrm{l}_{\mathrm{l}}$, onun üzerine ifsat edici bir leke gibi düşen ecnebi kaideleri atmalıyız. Arabi ve Farisi edatları asla kullanmamalıyı. Hele terkipleri mutlaka Türkçe kaidesiyle yapmalıyz. O vakit lüzumsuz olan Arabi ve Farisi kelimelerin kendi kendilerine savuştuklarını göreceksiniz (Genç Kalemler, C. II, S. ı). 


\subsection{Türk Dili ile ilgili Eserleri}

\subsubsection{Müntehabat-1 Durub-1 Emsal}

Ahmet Vefik Paşa Türk dili ve folkloru bakımından önemli bir eser olan Müntehabat-ı Durub-ı Emsalde Türk atasözlerini toplamış, bunun yanında deyimler (ipini kopardı, bağrına taş bastı, kendini dev aynasında görmüş, saman altından su yürütür, tabanı yağlamış vb.), tekerlemeler (Istanbul karış muruş alsana bir kara kuruş, pırpır eder uçamaz, çukura düşmüş̧ çıkamaz vb.), özlü bir anlam ifade eden beyit ve misralar (Kerem gördükçe ey Baki gedalarda reca artar, geçmiş zaman olur ki hayali cihan değer vb.)la halk diline yerleşmiş benzetme ve sözleri (kedi gibi nankör, sarı çıyan, şıkır şıkır, sağlık hastalık bizim için, köstebek gibi yere yapışmış) de kitabına almıştır. Bu bakımdan Ahmet Vefik Paşa'nın eserinde her türlü halk söyleyişine yer verdiği söylenebilir.

Müntehabat-ı Durub-ı Emsal, Ahmet Vefik Paşa'nın ikinci eseridir ve kitabın üzerinde Müntehabat-ı Durub-ı Emsale ek olarak bir de Atalar Sözü ifadesi vardir ${ }^{15}$.

Ömer Faruk Akün İslâm Ansiklopedisine yazdı̆̆ı Ahmet Vefik Paşa maddesinde, millî kültüre ve halkın diline duyduğu büyük ilginin, Şinasi gibi Ahmet Vefik'i de Türk atasözlerini toplamaya sevk ettiğini, Şinasi'nin 1863'teki ilk bask1sından sonra 1870'te daha genişletilmiş yeni baskısını yaptı̆̆ı Durub-ı Emsal-i Osmaniye'sinin ardından Ahmet Vefik'in 187l'de ortaya koyduğu bu eserin hep 1852'de basıldığının sanıldığını, bu sebeple kitabın Şinasi'ye ve devrin 1852'den beri bu sahadaki diğer çalışmalara öncülük ettiği gibi yaygınlaşmış pek yanlış bir hükmün var olduğunu belirttikten sonra söze devamla şöyle demektedir: Şinasi'nin, atasözlerini çok defa halis ifadeleri yerine divan şiirinde ve münevverlerin dilinde değişiklik görmüşs şekilleriyle nakleden eserini kendi elindeki malzemeye nispetle yetersiz bulduğu anlaşılan Ahmet Vefik, esas ağırlığı halk ağzındaki söyleyişlere verdiği çok geniş derleme mahsulü olan kitabında Şinasi'deki mevcudu birkaç misline çıkarır ve Bursa valiliği sırasında eserini daha da geliştirerek 168 sayfa olan ilkinden en aşağı bir katı kadar hacim kazanmış ve atasözlerini yer yer varyantları ile gösteren, bu defa adını Müntehabat-ı Durub-ı Emsal-Atalar Sözü̈ne çevirdiği 303 sayfalık yeni bir baskısını yapar ${ }^{16}$.

\footnotetext{
${ }^{15}$ Üzerinde yazarı ve basım tarihi bulunmayan bu eserin adı Ahmet Vefik Paşa'nın özel kütüphanesinde (Nu. 697) Durub-ı Emsal-i Osmaniye olarak gösterilmiş ve ìstanbul'da 1268 (1852) tarihinde basıldığı kaydedilmiştir. Bu tarih doğru ise Hıfzînin 1262 (1846)'de yayımlanan eserinden sonra ülkemizde basılan ikinci Türkçe atasözü kitabı Ahmet Vefik Paşa'ya aittir (Tansel (1), a.g.m., 136).

${ }^{16}$ Akün (1), a.g.m., 152.
} 
Ömer Faruk Akün ayrıca, eserin iki ayrı baskısının olduğunun bilinmeyip sadece bir baskısının tanınması sonucu hakkında verilen bilgi ve hükümlerin hep eksik ve sathi kaldığını, iki baskı arasında fark diye bir mesele hatıra gelmediğini belirtir ve son zamanlarda atasözleriyle ilgili bazı monografilerde Ahmet Vefik'in kitabının ayrıca Türkî Durub-i Emsal adını da taşıyan ilk baskısının 1288 olan neşir tarihinin 1287'ye çevrilerek Ahmet Mithat Efendi'ye mal edilmesinin devam eden yanlışlardan biri olduğunu, buna karşılık Bursa baskısının Müntehabat-ı Durub-ı Emsal-i Türkiyye şeklinde uydurma bir ad altında, "içinde 300 atasözü vardır" diye de bir kayıtla 1871'de ístanbul'da Matbaa-i Amire'de basılmış gösterilmesiyle bu yanlışlara yenilerinin de ilave edildiğini vurgular ${ }^{17}$. Akün'ün Ahmet Vefik Paşa'ya ait olduğunu söylediği Türkî Durub-ı Emsal adlı eserin sahibinin kaynakların çoğunda Ahmet Mithat Efendi olarak gösterildiğini burada söylemek gerekir.

İçerisindeki sözlerin alfabetik sıraya göre dizildiği üç yüz sayfayı aşan Müntehabat-ı Durub-ı Emsal, daha sonraları kendinden sonraki çalışmalara devamlı ve kolay kolay tüketilmeyen bir kaynak olmuştur. Nitekim Tekezade M. Sait Bey'in, Cümel-i Müntahabe-i Türkiyye -yahud- Atalar Sözü (istanbul 1313, M. 1895-96) adlı ve 5742 atasözünü içine alan eserinde Ahmet Vefik Paşa'nın Atalar Sözü̈nden faydalandığı bilinmektedir.

Müntehabat-ı Durub-ı Emsal Recep Duymaz tarafından yayımlanmıştır ${ }^{18}$.

Müntehabat-1 Durub-1 Emsal'den Örnekler

Aba vakti aba alan, yaba vakti yaba alan aldanmamıs.

Acele işe şeytan karışır.

Acı patlıcanı kırağı çalmaz.

Açın karnı doyar, gözü doymaz.

Adalet ile zulüm bir yerde durmaz.

Baba bilgisiyle adam, adam olmaz.

Bağrına taş bastı.

Bahtı bağll.

Bahtına küskün.

Bahtım olsaydı, anamdan kız doğardım.

Bal dök de yala.

Balta girmedik orman.

Baltayı taşa vurdu.

Çenesi düşük kocakarı.

${ }^{17}$ Akün (1), a.g.m., 152.

${ }^{18}$ Recep Duymaz, Atalar Sözü, Gökkubbe Yayınları, İstanbul 2005. 
Çerden çöpten.

Çeşmeye gidenin testisi kırılır.

Çok bilen çok yanılır.

Çok naz âşık usandırır.

Culsuz tazı.

Çürük baklanın bir kör alıcısı olur.

Çürük bina temel tutmaz.

Çürük iple kuyuya inilmez.

Emanete hryanet olmaz.

Er isen çık meydana.

Er olan meydana çıksın.

Erken kalkanın kısmeti gür olur.

Eski hamam eski tas.

Eski süpürgeyi dama atarlar.

Eskiye rağbet olsa bit pazarına nur yağar.

ilim bir noktadan ibaretmiş.

ilim yalnız cehli giderir.

Imam bayıldı, müezzin ayıldı.

inadı inattır.

ince eleyip sik dokuma.

insan insana lazım olur.

insan kısmetini aramazsa kısmet insanı arar.

Kem küm etmekten doğruyu söyleyemez.

Kem söz, kem akçe sahibinindir.

Kendi düşen ağlamaz; iki gözü birden çıkar.

Kendi düşen kendi kalkar.

Kendi etti kendi buldu.

Kendinden paha biç.

Kendini dev aynasında görmüş.

Keramet bizim sopada.

Sağlık varlıktan yeğdir.

Sahipsiz tahtayı el almazsa yel alır.

Saman altından su yürütür.

Saman gibi ne tadı var ne tuzu.

Sana taşla dokunana sen pamukla dokun.

Sanat elde altın bileziktir.

Şöyle böyle derken akşam oldu.

Şunun bunun günahına girer.

Şurası senin burası benim.

Şükür ve sena nimeti artırır. 
Taban tabana zit.

Tabanı kaldırdı.

Tadindan yenmez oldu.

Tadı tuzu yok yavan bir söz.

Tafra vurdukça...

Takdir-i Huda kuvvet-i bazu ile dönmez; bir şem’a ki Mevla yaka hiçbir vech ile sönmez.

Tamtakır kuru bakır.

Tası tarağı topladı.

Tas tasa baş başa.

Tasadan oldu köse.

Tası tasa tasmayı koyuna.

Taş atıp da kolun mu yoruldu?

Taşı başına mih dişine.

Yıldızımız barışmadı.

Yrrtıcı kuşun ömrü az olur.

Yiğidin karası atın dorusu.

Yol yordam bil.

Yuvay dişi kuş yapar.

Yükünü tuttu.

Yürek üzüntüsü.

Yüze yüze kuyruğuna geldik.

Yüzmek, yoğurt ezmek, yazı yazmak unutulmaz marifettir.

Zahiri batınına uymaz.

Zahmet çeken rahat olur.

Zahmetin noktası kalkar rahmet olur.

\subsubsection{Lehce-i Osmani}

Türk sözlükçülügünün dönüm noktası kabul edilen Lehce-i Osmaniyi Ahmet Vefik Paşa Şûra-yı Devlet Üyeliğinden azledildiği zaman -1873-1876 yılları arasında- hazırlamış, başvekillikten ayrıldığı 1882'den sonra eserini geliştirip ikinci basımını yapmıştır ${ }^{19}$. Hiçbir ayrım yapılmadan Türkçe, Arapça ve Farsça kelimelerin birlikte ele alındığı ilk baskıdan sonra Ahmet Vefik Paşa Lehce-i Osmaninin ikinci basımını gerçekleştirmiştir. Bu baskının l. cildinde Türkçe kelimelerle, Türkçeleşmiş kabul edilen Arapça ve Farsça kelimeler yanında Batı dillerinden gelip günlük dilde kullanılan kelimelere yer verilmiş; yalnızca yazı dilinde kullanılan Arapça ve Farsça kelimeler de sözlüğün 1l. cildine alınmıştır.

19 Lehce-i Osmani birinci baskı, Tab'hâne-i Âmire, Recep 1293 (1876), 1294 sayfa; ikinci baskı, Mahmut Bey Matbaası, ìstanbul 1306 (1890), 1455 sayfa. 
"Avam sözü” diye o zamana kadar hor görülmüş söz ve deyimlere ön planda yer vermekle dilde sadeleşme ve millîleşme düşüncesinin şuurlu bir gerçekleştiricisi oluşu yanında, Türkiye Türkçesindeki kelimelerin asli anlam ve imlalarını Doğu Türkçesinde arayan, Türkçenin sözlerini türedikleri kök etrafında toplayıp açıklayan bir yol takip etmesi ile de Türk lügatçiliğinde önemli bir merhale sayılan Lehce-i Osmaninin yazılış sebebini İsmail Hikmet şu şekilde izah etmektedir: Vefik Paşa, lisanın bütün güç, çapraşık ve eksik noktalarını görüyordu, imladan başlayarak lügate ve inşaya kadar her cihetinin sslaha muhtaç olduğu noktaları bulunduğunu pek güzel görüyordu. Bir kere lisanın aslı olan Türk kelime ve unsurlarının Arap ve Acem kelimelerinin istilaları altında unutula unutula ezilip gittiğini, yerine bütün ecnebi unsurların dile akın ettiğini görüyor ve canı sıkılıyordu. Bu yüzden günün birinde Türk'ün asıl dili tamamıla unutulup gidivereceğini düşünüyordu. Bu tehlikeye karşı koymak için bir çare düşündü. Esasen iyiden iyiye tetkik etmiş olduğu eski Türk lehçelerini gözünün önüne getirdi. $\mathrm{Bu}$ ana dili unutturmamak için gelecek nesillere bir hatıra, bir yadigâr bırakmak istedi. Lehce-i Osmânî adıyla bir lügat kitabı yazdı ${ }^{20}$.

Denilebilir ki Ahmet Vefik Paşa'nın eserleri içinde başköşede duran ve onun fikrî, ilmî şahsiyetini tam anlamıla yansıtan eseri Lehce-i Osmanidir. Her ne kadar eser Lehce-i Osmani adını taşımakta ise de, bu ad ile kastedilen, doğrudan doğruya Türk dilidir. Aslında Lehce-i Osmani yayımlanana kadar ülkemizde Osmanlı sahasında Türk dilinin sözlüğünü yapmaya gerek görülmeyen bir anlayış devam etmiştir. Lehce-i Osmani işte bu anlayışın yıkılarak Osmanlı sahasında Türkçeden Türkçeye ilk millî sözlük olması vasfiyla özel bir önem taşımaktadır. Bugün için çok normal olarak görünen bu tutum yalnız Arapça ve Farsça kelimelerin sözlüklere alındı̆̆ı o devir için küçümsenmeyecek bir yenilik olarak görülmelidir. Bu lügat o zamana kadar yazılan lügatlerden bir noktada ayrılıyordu. Öteki lügatlar hep Arap ve Acem kelimelerine ehemmiyet veriyorlar. O kelimelerin dilde yerleşmesini temine uğraşıyorlardı. Vefik Paşa'nın Lehce-i Osmani'si bilhassa aslen Türk olan kelimelere ehemmiyet veriyordu. Diğer lügatlerde bulunmayan Türkçe kelimeler Vefik Paşa'nın lügatinde en mühim yeri işgal ediyordu ${ }^{21}$.

Eserin ihtiva ettiği Türkçe kelime ve tabirler yüzünden, yayımlandı̆̆ zaman oldukça yadırgandığını burada belirtmek gerekir. Öteden beri Ahmet Vefik Paşa aleyhinde bulunan Namık Kemal, damadı Menemenli Rifat Bey'e yolladığı 31 Ağustos 1880 tarihli mektubunda "Lehce-i Osmani Buhara, veyahut Divrik halkı için yapılmış; binaenaleyh görülecek güçlük Türkçe meselesidir." der; vefatından bir yıl kadar önce yazdığı 19 Aralık 1887 tarihli ve yine Rifat Bey'e gönderdiği

${ }^{20}$ ismail Hikmet (Ertaylan), Ahmet Vefik Paşa, Kanaat Kütüphanesi, ìstanbul 1932, s. 21.

${ }^{21}$ Ertaylan, a.g.e., 21-22. 
mektubunda, bu lügate herhâlde ihtiyaç hissetmiş olmalı ki, “Ahmet Vefik'in Türkçe bir lügat kitabı var idi. ismi bilmem ne karın ağrısı idi; ondan bana bir takım al da gönder." demektedir. Ahmet Mithat Efendi'nin "Bin kişiden fazla, bunun muahazesine dair sözler işittim: 'Canım böyle lügat mi olur? lçcmek, süpürmek gibi kelimeleri kim bilmez ki?.. Onların manalarını bize öğretmek için Lehçe'ye yazmış' gibi muahazeler ki erbabının bir lisan ve o lisanın kamusunun ne demek olduğunu bilmediklerini delalet eder." ifadesi çağdaşlarına göre çok ileri görüşlü Vefik Paşa'nın bu eserinin o devirde nasıl yadırgandığını açıkça gösterir; fakat zamanla onun, Osmanlıcanın bir dil değil, Türk dilinin bir lehçesi olduğu hakkındaki doğru görüşü anlaşılmış, Türkiye'de milliyet fikirlerinin gelişmesinde oynadığı mühim rol, bilhassa bu eseri dolayısıyla gerek memleketimizde, gerek Batı dünyasında dikkati çekmiştir ${ }^{22}$.

Lehce-i Osmani, Şeyh Süleyman Efendi, Redhouse, Radloff ve Şemseddin Sami gibi birçok müellifin sözlüklerine de kaynaklık etmiştir. Kaynaklarda Barbier de Meynard'ın hazırladığı Dictionnaire Turc-Français, Supplément Aux Dictionnaire Publiés Jusqu'à Ce Jour adlı büyük lügatin (Paris, 1881-1886) doğrudan doğruya Lehce-i Osmaniden çıktığı dahi yazmaktadır.

Yukarıdaki ön bilgilerden sonra Lehce-i Osmaninin başlıca özelliklerini şu şekilde sıralayabiliriz:

1. Tamamı 1455 sayfa olan sözlüğün 856 sayfalık ilk kısmı Türkçe ve Türkçeleşmiş kabul edilen Arapça, Farsça ve Batı kökenli kelimelere ${ }^{23}$ ayrılmıştır. Eserin geri kalan ikinci kısmında Arapça ve Farsçadan alınan ve daha çok yazı dilinde kullanılan kelimeler verilmiştir.

2. Lehce-i Osmani'de her harf bir bab sayılmış; bu bablar da kelimelerin ilk hecesindeki hareke (ünlü)ye göre üç "fasl”a ayrılmışıı: "Kaf babı: kaf-ı meftûha faslı, kaf-ı mazmûme faslı, kaf-ı meksûre faslı" gibi. Ancak eserde alt sınıflamaya (fasıl) tam uyulmamıştır. Bu durumlarda kelimenin telaffuzuna "meftûh, mazmûm, meksûr" terimleriyle işaret edilmiş veya n. (=nazar oluna "bakınız") kısaltması ile ilgili kısma gönderilmiştir. Ünlüyle başlayan kelimeler alfabenin özelliği gereği- zorunlu olarak "elif" harfinde dokuz alt başlık altında toplanmıştır. Burada dikkati çeken husus kapalı e (elif ma'a yâ-yı mechûle) sesine de ayrı bir fasıl ayrılmasıdır ${ }^{24}$.

\footnotetext{
${ }^{22}$ Tansel (11), a.g.m., 254-255.

${ }^{23}$ Lehce-i Osmanideki Batı kökenli kelimeler için bk. Hüseyin Yıldız, "Ahmet Vefik Paşa'nın Lehce-i Osmani'si ve Batı Kaynaklı Kelimeler", Türk Dili, C: LXXXVIII, S: 634, s. 439-446, Ankara 2004.

${ }^{24}$ Avni Gözütok, "Türkiye Türkçesinin Ilk Sözlüğü Lehce-i Osmani”, Fen-Edebiyat Fakültesi Edebiyat Bilimleri Araştırma Dergisi, Atatürk Üniversitesi Yayınları, S. 24, Erzurum 1997, s. 33.
} 
3. Lehce-i Osmanide mümkün olduğu kadar Doğu Türkçesindeki asılları ve eski şekilleriyle gösterilen madde başı kelimeler, ilk olarak köklerine göre sıralanmış ${ }^{25}$; kökün anlamı verildikten sonra bundan türeyen yeni şekiller ve deyimler açıklanmıştır. Aynı kökten türeyen sözlerin ayrı madde başlarına dağılmadan bir arada bulunması Türkçenin söz konusu dönemdeki kelime ve deyim teşkilindeki zenginliğini ortaya çıarması bakımından da önemlidir. Fakat burada hemen belirtelim ki Lehce-i Osmanide madde başlarının verilmesinde tam bir düzen görülmemektedir. Yapım ekiyle teşkil edilen şekiller bazen madde başı olarak alınmakta, çoğu kez de madde içinde gösterilmektedir. Yine nispet îsiyle yapılan Arapça ve Farsça kelimelerle cali mastar eki almış kelimeler de bazen madde başı olarak verilmekte, bazen de madde içinde sıralanmaktadır.

at maddebaşı altında atlu, atlamak, atlandırmak, atlambaç, atlangıç, atlatmak, atlama kelimeleri ve bunlarla ilgili birleşik yapılar ve deyimler sıralanmıştır. Kelimelerin birden fazla karşılıkları arasına herhangi bir işaret konulmadığından karşılıkları okumak ve ayırmak oldukça zordur. at maddebaşı ile köken ve anlamca ilgisi olmayan, fakat imlaları yakın olan atılmak atış atmak kelimelerinin (oLÔ $\left.\neg \mathrm{gšO}_{\neg} \mathrm{oL}^{*} \hat{\mathrm{O}} \neg\right)$ imlâlarına bakılması salık verilmektedir.

A. Vefik Paşa atmak, atışdırmak, atdırmak, atışmak, atılmak, atılmış, atlayış, atma, atıcı, atış, atkı, atkılamak, atık, atım kelimelerini ise ayrı ayrı maddebaşı alarak tanımlamışır. A. Vefik Paşa'nın Lehce-i Osmanisi bu açıdan tutarsız olup, hangi türevlerin ve birleşik yapıların maddebaşı olacağı konusunda kesin bir bilgisi ve ölçütü yoktur ${ }^{26}$.

Söz konusu kusuru Servet-i Fünun yazarlarından Ahmet ihsan (Tokgöz) da görmüş ve Lehce-i Osmaninin önemini dile getirdikten hemen sonra sözlüğün biçim ve basımındaki düzensizlikten bahsetmiştir: Lisânımızda hemen ilk defa olmak üzere tertîb edilen lügat Lehce-i Osmânî dir, Lehce-i Osmânî kelimât1 Türkiyye'nin bir sûret-i basîtede cem'inden ibâretdir. Fakat hiç yokdan böyle bir eserin tertîbi o kadar gücdür ki lügat ile biraz iştigâli olanlar bu bâbdaki suûbeti takdîr ederler. Lehce'nin fevâid-i mahsûsasından biri de lisânımızın tekemmülü husûsunda bir me'haz-ı âlî olmasıdır. Ekser kelimât-ı Türkiyye'nin

\footnotetext{
25 Türemiş şekillerinin yaşamasına karşılık unutulmuş veya kullanılmaz olmuş kök kelimelere götüren, Osmanlı Türkçesiyle olan ilgiyi veya farkları göstermeye yönelen bu sistem, eseri Doğu Türkçesine açtığı için, Thory Jozsef ve Barbier de Meynard gibi Batılı Türkologlarca Türkçenin mukayeseli incelemesine kaynak bir çalışma olarak gösterilmiştir. Kullandığı kaynakları zikretmeyen Ahmet Vefik Paşa'nın sözlügü hazırlarken Doğu Türkçesiyle yazılmış eserlerden faydalandığı anlaşılmaktadır [Ömer Faruk Akün (II), "Ahmet Vefik Paşa", Türkiye Diyanet Vakfı ìslâm Ansiklopedisi, C. 2, ìstanbul 1989, s. 128].

${ }^{26}$ Paşa Yavuzarslan, Osmanlı Dönemi Türk Sözlükçülüğü, Tiydem Yayıncılı, Ankara 2009, s. 129-130.
} 
ma'nâ-yı mecâziyesi bir sûret-i münâsebede dermeyân edildiğinden câmiiyyet nokta-i nazarından da mühimdir. Garîbdir ki tertîb olunan bazı lügatlerde me'hazlar tadât olunurken Lehce'de zikrolunmamıştır. Lehce'nin kusûru sûret ve usûl-i tab'ndaki adem-i intizâmdan ibârettir (Servet-i Fünun, sayı 3, s. 29).

4. Ahmet Vefik Paşa'nın Lehce-i Osmaniyi hazırlarken halk ağzı söz varlığından ve Türkçe metinlerden yararlandığı bir gerçektir. Eserde kelimeler açıklanırken örnek olarak verilen deyimler, konuşma dilinin özelliklerini taşıyan ifadeler onun halk dili kaynağını gösterir: top yoluna gitmek: heder, telef olmak (s. 585), tuzluca oturdu: pek pahalı geldi (s. 545), göze dize durmak: nankörlük cezası $(\text { s. } 731)^{27}$.

5. Eserde madde başı olarak alınan kelimeler anlamlandırılırken daha çok, madde başlarının Arapça ve Farsçadaki karşılıklarının verilmesi şeklinde bir yol izlenmiştir: anlayış: zekâvet, intikal, idrak, tefehhüm, fetanet, feraset; bıçkı: erre, testere, minşâr, büyügü hızar; gezmek: seyir, teferrüç, temaşa etmek, sefer, seyahat, devir, tedavül etmek, seyyah, tayyar olmak gibi.

6. Arap harfleriyle yazılan metinlerde yer alan birbirine yakın $/ 1 /-/ i /, / o /-/ 0 /$ , /u/-/ü/ ünlülerini ayırt etmenin oldukça güç olduğunu fark eden Ahmet Vefik Paşa, Lehce-i Osmanide Türkçenin tek harfte toplanmış ayrı ve farklı seslerinin belli olması için çözüm önerileri getirmiş ve Arap alfabesinde sadece $و$ harfiyle gösterilen Türkçedeki /o/, /ö/, /u/, /ü// seslerinin her biri için ayrı ayrı işaretler

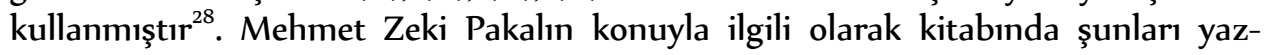
maktadır: Arap harflerinin başa çıkılmaz güçlükleriyle uğraşmak için her musannif kendine göre bir usul koymuş, mesela Ahmet Vefik Paşa merhum Lehce'sinde sadalı harflerden $(o, \ddot{u}, u, \ddot{o})$ sadalarını yerine göre eda eden $v$ harfinin çanağına bir nokta koymuş ve buna zamme-i muhaffama demiş, altına bir nokta koyarak

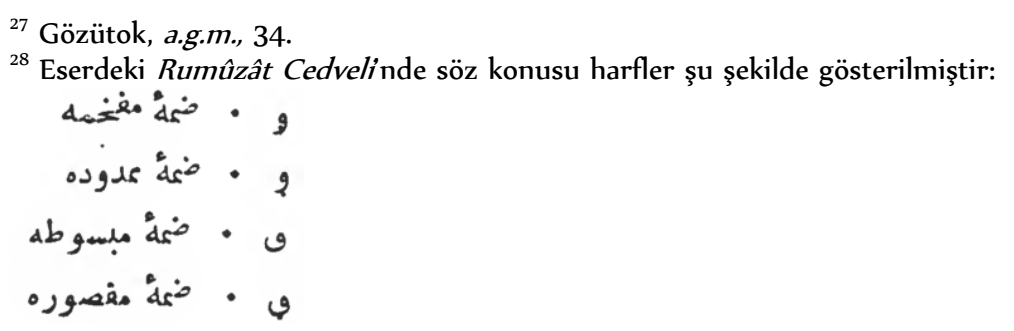

Zamme-i mufahhame [vâv harfinin kuyruğunun kavisi dikey ve kısa]

Zâmme-i memdûde [vâv harfinin kuyruğunun kavisi dikey ve kısa ayrıca harfin altına nokta konulmuş]

Zamme-i mebsûta [vâv harfinin kuyruğunun kavisi yuvarlak ve uzun]

Zamme-i maksûre [vâv harfinin kuyruğunun kavisi yuvarlak ve uzun ayrıca harfin altına nokta konulmuş] 
zamme-i memdûde, noktasız kaf harfi gibi şekilde yazarak zamme-i mebsûta ve bu şeklin altına bir nokta ilave etmek suretiyle zamme-i maksûre ismini vermiş ve lügatte bu usulü takip etmişş.

7. Ahmet Vefik Paşa ünsüzlerle ilgili karışıklı̆̆ın da farkına varmış; bu itibarla Türkçede bulunan sağır nun ünsüzü için S harfini, görmek kelimesindeki g'yi keften ayırmak için

8. Balık, baş, Batum, Bayburt, çadır, Çağatay, çam, coğrafya, Çingiz, elifba, gemi, Türk, yeniçeri gibi madde başları esere bir ansiklopedik sözlük niteliği kazandırmıştır.

9. Lehce-i Osmanide bazı madde başlarının izahında Osmanlı Türkçesi ve Doğu Türkçesinden örnek beyitler zikredilmişse de bunların kime ait olduğu belirtilmemiştir.

10. Eserde toplam 6329 madde başı vardır. 45 tanesi İtalyanca, 13 tanesi Rumca, 12 tanesi Fransizca, 8 tane Yunanca, 2 tane Latince, 2 tane İngilizce, 1 tane Almanca, 1 tane ibranice, 1 tane Hintçe kelime vardır ${ }^{31}$.

Lehce-i Osmani, ikinci basımı esas alınarak Prof. Dr. Recep Toparlı tarafindan Latin alfabetik sistemine göre yeni harflere çevrilmiş, her iki cildi için ayrıca Arap harflerine göre birer dizin ilave edilerek yayımlanmışıı ${ }^{32}$.

\section{Sonuç}

Bir devlet adamı, bir diplomat olan Ahmet Vefik Paşa aynı zamanda döneminin ileri gelen kültür adamlarındandır. Yüksek temsil yeteneği ile dillere destan bir devlet adamı portresi ortaya koyan, gözünü budaktan esirgemeyen, doğru bildiği yolda tek başına da kalsa yürümekten vazgeçmeyen ve bu yüzden sık sık azledilen Paşa, en zor ve sıkıntılı günlerini bile bir fırsata dönüştürmeyi bilmiş, bu aralıkları Türk tarihine ve kültürüne hizmet için değerlendirmiştir.

Tarihle ilgili olarak kaleme aldıkları, bu alana olan vukufiyetini göstermekle beraber, Paşa, asıl mesaisini dil alanına, Türkçeye hasretmiştir. Doğu dilleri ve Batı dilleri karşısında Türk dili lehinde ve yanında şuurlu duruşu bu alandaki doğru gelişime önemli bir katkı sağlamıştır.

${ }^{29}$ Pakalın, a.g.e., 215.

${ }^{30}$ Bahriye Çeri, Ahmet Vefik Paşa Devir-Şahsiyet-Eser, Hacettepe Üniversitesi Sosyal Bilimler Enstitüsü Doktora Tezi, Ankara 1997, s. 157.

${ }^{31}$ Ertuğrul Topbaş, 1875-1905 Yılları Arasındaki Sözlükler Üzerine Bir Inceleme, Gazi Üniversitesi Sosyal Bilimler Enstitüsü Yüksek Lisans Tezi, Ankara 1987, s. 14.

${ }^{32}$ Recep Toparl, Lehce-i Osmani, Türk Dil Kurumu Yayınları, Ankara 2000. 
Ahmet Vefik Paşa, vakarlı devlet adamlı̆̆ı ve gayretli kültür adamlı̆ı kimliği ile gösterdiği yararlıklar çerçevesinde hiç unutulmayacak, hep hayırla yad edilecektir.

\section{KAYNAKÇA}

AKÜN, Ömer Faruk, "Ahmet Vefik Paşa”, Türkiye Diyanet Vakfı islâm Ansiklopedisi, C. 2, s. 143157, istanbul 1989.

, Ömer Faruk, "Lehce-i Osmânî", Türkiye Diyanet Vakfi İslâm Ansiklopedisi, C. 23. s. 127-128, istanbul 2003.

ÇERi, Bahriye, Ahmet Vefik Paşa Devir-Şahsiyet-Eser, Hacettepe Üniversitesi Sosyal Bilimler Enstitüsü Doktora Tezi, Ankara 1997.

DEVELLiOĞLU, Ferit, Osmanlıca-Türkçe Ansiklopedik Lûgat (Eski ve Yeni Harflerle), Aydın Kitabevi Yayınları, Ankara 1995.

DUMAN, Musa, "Yenileşme Döneminde Türk Dili" Türkler Ansiklopedisi, C. 15, Yeni Türkiye Yayınları, s. 102-130, Ankara 2002

DUYMAZ, Recep, Atalar Sözü, Gökkubbe Yayınları, ìstanbul 2005.

GÖZÜTOK, Avni, "Türkiye Türkçesinin ilk Sözlüğü Lehce-i Osmani”, Fen-Edebiyat Fakültesi Edebiyat Bilimleri Araştırma Dergisi, Atatürk Üniversitesi Yayınları, S. 24, s. 29-37, Erzurum 1997.

GÜRAY, Sevim, Ahmet Vefik Paşa, Türk Dil Kurumu Yayınları, Ankara 1991.

iNAL, ibnülemin Mahmut Kemal, Son Sadrazamlar, C. 2, Dergâh Yayınları, i̇stanbul 1982.

İsmail Hikmet (ERTAYLAN), Ahmet Vefik Paşa, Kanaat Kütüphanesi, İstanbul 1932.

KORKMAZ, Zeynep, "Ahmet Vefik Paşa”, Türk Dili, C. Lll, S. 422, s. 77-98, Ankara 1987.

KúNOS, lgnácz, Türk Halk Edebiyatı, hzl. Tuncer Gülensoy, Tercüman 1001 Temel Eser, ìstanbul 1978.

Mehmed Süreyya, Sicill-i Osmanî 1, hzl. Nuri Akbayar, Eski Yazıdan Aktaran: Seyit Ali Kahraman, Tarih Vakfi Yurt Yayınları, ìstanbul 1996.

PAKALIN, Mehmet Zeki, Ahmet Vefik Paşa, Ahmet Sait Matbaası, ìstanbul 1942.

SEVÜK, İsmail Habip, Türk Teceddüd Edebiyatı Tarihi, Matbaa-i Âmire, İstanbul 1925.

TANSEL (1), Fevziye Abdullah, "Ahmet Vefik Paşa”, Belleten, Türk Tarih Kurumu Yayınları, C. XXVIII, S. 109, s. 117-139, Ankara 1964.

(11), Fevziye Abdullah, “Ahmet Vefik Paşa'nın Eserleri”, Belleten, Türk Tarih Kurumu Yayınları, C. XXVIII, S. 110, s. 249-283, Ankara 1964.

TOPARLI, Recep, Lehce-i Osmani, Türk Dil Kurumu Yayınları, Ankara 2000.

TOPBAŞ, Ertuğrul, 1875-1905 Yılları Arasındaki Sözlükler Üzerine Bir İnceleme, Gazi Üniversitesi Sosyal Bilimler Enstitüsü Yüksek Lisans Tezi, Ankara 1987.

YAVUZARSLAN, Paşa, Osmanlı Dönemi Türk Sözlükçülüğü, Tiydem Yayıncılık, Ankara 2009.

YILDIZ, Hüseyin, “Ahmet Vefik Paşa'nın Lehce-i Osmani'si ve Batı Kaynaklı Kelimeler”, Türk Dili, C: LXXXVIII, S: 634, s. 439-446, Ankara 2004. 